Article

\title{
Spatiotemporal Dynamics of Carbon Storage in Response to Urbanization: A Case Study in the Su-Xi-Chang Region, China
}

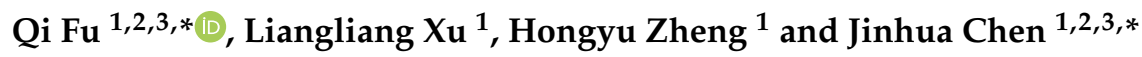 \\ 1 School of Politics and Public Administration, Soochow University, 199 Ren'ai Road, SIP, \\ Suzhou 215123, China; xull_99@163.com (L.X.); hyzheng@suda.edu.cn (H.Z.) \\ 2 Collaborative Innovation Center for New-type Urbanization and Social Governance of Jiangsu Province, \\ 188 Ren'ai Road, SIP, Suzhou 215123, China \\ 3 Research Institute of Metropolitan Development of China, Soochow University, 199 Ren'ai Road, SIP, \\ Suzhou 215123, China \\ * Correspondence: fuqi@suda.edu.cn (Q.F.); jhchen@suda.edu.cn (J.C.); \\ Tel.: +86-166-5112-0669 (Q.F.); +86-139-0620-8289 (J.C.)
}

Received: 30 August 2019; Accepted: 7 November 2019; Published: 9 November 2019

\begin{abstract}
Terrestrial ecosystem carbon storage plays an important role in mitigating global warming. Understanding the characteristics and drivers of changes in carbon storage can provide a scientific basis for urban planning and management. The objective of this study was to reveal the ways in which urbanization influences the spatial and temporal variations in carbon storage. In this study, we investigated the changes in carbon storage from 1990-2000, 2000-2010, and 2010-2018 in the $\mathrm{Su}-\mathrm{Xi}$-Chang region, which is a typical fast-growing urban agglomeration in China, based on the InVEST (Integrated Valuation of Ecosystem Services and Tradeoffs) model. Moreover, we analyzed the impacts of urbanization-induced land-use changes on carbon storage. The results showed that in terms of space and time, the greatest loss of carbon storage occurred in developing urban areas and during the rapidly urbanizing stage. Our study revealed that the reduction in cultivated land was the greatest contributor to carbon stock losses. In addition, we found that some types of land use conversion can enhance carbon storage. Based on the results, some suggestions are proposed aimed at promoting urban sustainable development. This study also provides insights into enhancing urban sustainability for other urban agglomerations throughout the world.
\end{abstract}

Keywords: urbanization; carbon storage; land-use change; spatiotemporal dynamics; InVEST model

\section{Introduction}

As an important part of the global carbon cycle, carbon storage in terrestrial ecosystems has attracted extensive attention from scientists and governments worldwide [1-4]. Terrestrial ecosystems can reduce and mitigate climate change by absorbing atmospheric carbon and storing it in soil and plant organic matter [5,6]. However, excessive human activities lead to unbalanced carbon budgets in terrestrial ecosystems, which aggravate global warming [7]. Wildfires, timber harvesting, land management, and land use/land cover change (LUCC) all result in changes in ecosystem carbon storage [8-10]. Among them, LUCC is considered to be one of the most important factors causing carbon storage changes in global terrestrial ecosystems [11,12].

"Urbanization" refers to the population shift from rural to urban areas and the continuous expansion of urban scale [13]. To date, more people than ever live in cities, and the level of urbanization is continually increasing. It is predicted that by 2050, the proportion of the global population living in cities and towns will reach 70\% [14]. Another study shows that the total global urban land area is 
expected to triple from approximately 0.65 million $\mathrm{km}^{2}$ in 2000 to 1.86 million $\mathrm{km}^{2}$ in 2030 [15]. These findings indicate that the trend of urbanization will continue into the future. However, urbanization not only leads to economic development and population growth but also causes significant LUCC [16]. Relevant studies have shown that unreasonable LUCC in urbanization processes leads to declines in carbon storage, thus further affecting the climate regulation service of ecosystems and the sustainable development of human society $[17,18]$. Therefore, exploring the relationship between urbanization and carbon storage is helpful for a better understanding of the interaction between human beings and ecosystems and providing a basis for formulating sustainable urban development policies.

The methods used to estimate the relationship between urbanization and carbon storage change mainly include field surveys [19,20], remote sensing [21,22], and model assessment [23-26]. In recent years, the Integrated Valuation of Ecosystem Services and Tradeoffs (InVEST) model has been commonly used by researchers to evaluate carbon storage because of its low demand for input parameters and high accuracy of assessment results $[27,28]$. The InVEST model was developed by the Natural Capital Project (www.naturalcapitalproject.org), which is an integration of a series of modules for evaluating ecosystem services such as water yield, sediment retention, and carbon storage [29]. The carbon storage and sequestration module in the InVEST model can efficiently assess carbon storage in terrestrial ecosystems by using land-use type maps and carbon density values as input data. For example, Delphin et al. [30] revealed the driving mechanism of urbanization changes affecting carbon storage in two disparate watersheds in Florida, USA, based on the InVEST model. Tao et al. [31] applied the InVEST model to estimate the change in terrestrial carbon storage in Changzhou, China and found that the carbon density decreased with an increase in urban development intensity. Jiang et al. [23] used the InVEST model to investigate the impact of urban ecosystem changes on carbon storage in the Changsha-Zhuzhou-Xiangtan urban agglomeration under different scenarios. By combining the InVEST model and a new land-use monitoring method, Sallustio et al. [32] analyzed the impact of land-use changes on carbon storage in Rome and Molise in Italy.

Carbon storage not only changes with different stages of urbanization but also displays spatial heterogeneity across different regions, such as urban centers, suburbs, and rural areas. It is a challenging task to comprehensively investigate the impact of urbanization on spatial and temporal changes in carbon storage. For example, many studies analyzed the spatial patterns of carbon storage in the urban-rural gradient, however, they failed to reveal the impact of urbanization on carbon storage over time [33-35]. Other studies analyzed the relationship between urbanization and carbon storage for different periods but did not explore the differences in the spatial distributions of carbon storage in urban-rural structures [36-38]. Further, many studies have focused on the carbon stock losses caused by urban expansion [23,39-41], but urbanization can also increase carbon storage, which is often neglected. Therefore, the research efforts mentioned above are unable to provide comprehensive suggestions for the sustainable development of urban areas.

Since the reform and opening up of the country, China's urbanization has developed rapidly, with the urbanization rate increasing from $17.9 \%$ in 1978 to $58.5 \%$ in 2017 [42]. In addition to economic growth, rapid urbanization has also led to many ecological problems [43-45]. Therefore, promoting sustainable urbanization has become a major task that China must confront. To prevent land degradation, air pollution, and climate change, China has established a series of plans to protect and expand forests, these have contributed significantly to increases in ecosystem services such as carbon sequestration and soil retention [46,47]. Moreover, in the Paris Climate Agreement, China committed to reaching its peak carbon emissions in approximately 2030 and then achieving declines thereafter [48]. China's terrestrial ecosystems have played and will continue to play an important role in carbon storage [49]. Evaluating the spatial and temporal impacts of urbanization on carbon storage will help to reveal the problems facing urban development and provide inspiration for future urban planning.

In this study, the Su-Xi-Chang region, a typical fast-growing urban agglomeration in China, was selected as a case study to estimate the spatiotemporal dynamics of carbon storage in response to urbanization from 1990-2018. We first obtained the spatial patterns and different stages of urbanization 
based on nighttime light imagery data and demographic data. Then, by using the InVEST model, we assessed the changes in carbon storage and analyzed the reasons for the changes. The main objectives of our study were to (1) reveal how landscape patterns change spatially along the urban-rural gradient and temporally through the process of urbanization and (2) analyze the impacts of urbanization-induced land-use changes on carbon storage. Our results are expected to provide scientific support for the sustainable development of the Su-Xi-Chang region and a methodology that can be applied to other urban agglomerations with similar characteristics throughout the world.

\section{Materials and Methods}

\subsection{Study Area}

The Su-Xi-Chang region $\left(119^{\circ} 08^{\prime}-121^{\circ} 15^{\prime} \mathrm{E}, 30^{\circ} 46^{\prime}-32^{\circ} 04^{\prime} \mathrm{N}\right)$ (Figure 1), which includes the three cities of Suzhou, Wuxi and Changzhou, is located on a plain of the lower reaches of the Yangtze River in the south part of Jiangsu Province, which is one of the fastest-growing regions in China [50]. The study area belongs to the north subtropical monsoon climate, with an average annual precipitation of $1092.4 \mathrm{~mm}$ and an average annual temperature of $15.3^{\circ} \mathrm{C}$ [51]. The total land area of the three cities is 1.78 million ha, of which Suzhou accounts for $49 \%$, Wuxi, $26 \%$ and Changzhou, $25 \%$. By the end of 2018, the total population of the Su-Xi-Chang region had reached 22.225 million, with an average population density of 1233 people $/ \mathrm{km}^{2}$ [50]. The three cities are adjacent and are culturally connected and of similar size, which is very rare in China's urban patterns.

From the 1980s to the 1990s, a large number of rural enterprises with collective ownership emerged in the Su-Xi-Chang region, which greatly promoted local economic development. This mode of development is known as the "Sunan model" [52]. After 2000, the expansion of the urban development zones, the construction of transportation infrastructure and the influx of foreign capital drove the development of the high-tech manufacturing industry, which caused the study area to enter a stage of rapid urbanization. However, with rapid population growth and urban expansion, the demand for urban built-up areas continues to expand, and competition for agricultural and construction land has increased. At the same time, rapid urbanization has also caused water and soil pollution, increasing haze weather and seriously affecting local sustainable development $[51,53]$.
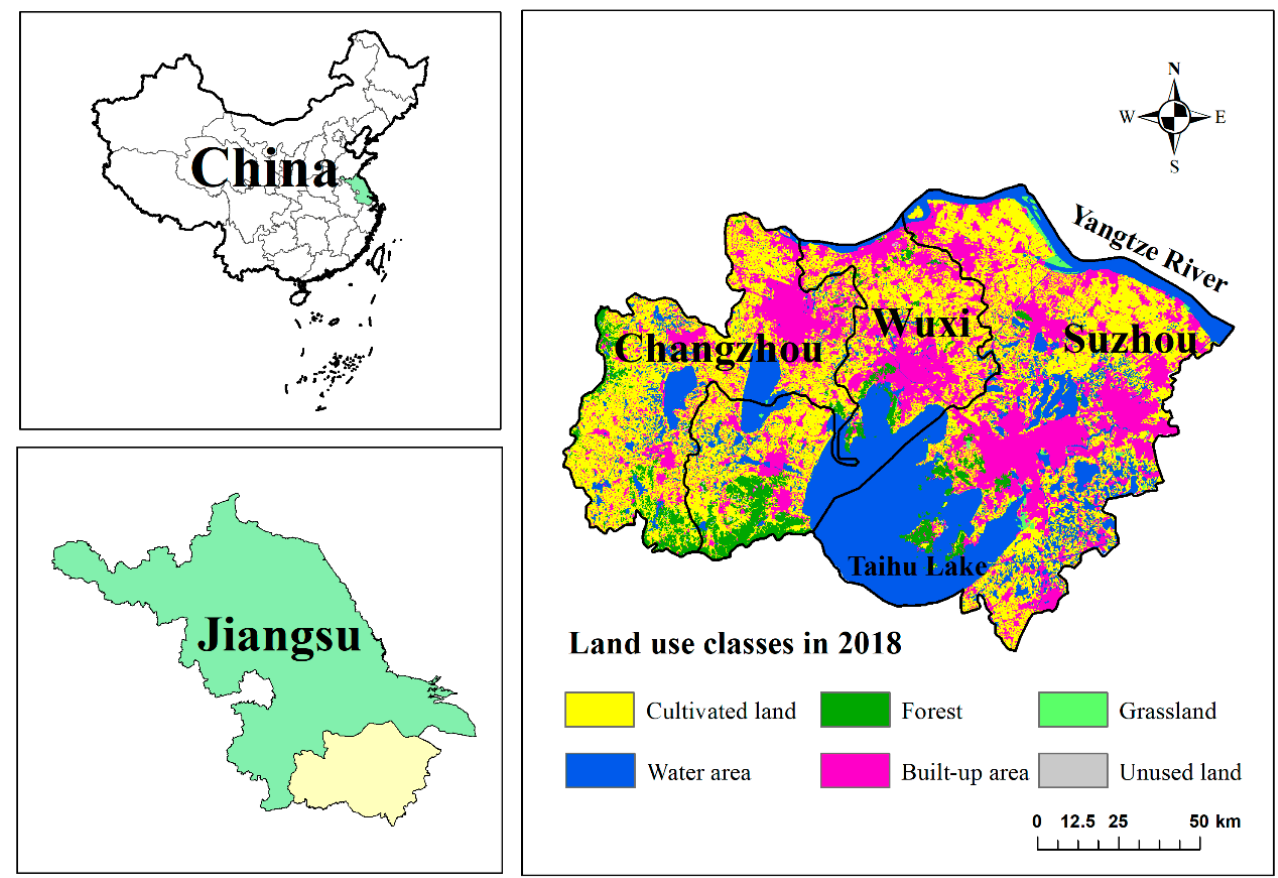

Figure 1. Location of the Su-Xi-Chang region. 


\subsection{Data preparation}

In this study, ArcGIS 10.2 (http://www.esri.com/software/arcgis) was used as the GIS software platform. All vector and raster data were converted to the same projection coordinate system (Krasovsky_1940_Transverse_Mercator). The land use data from 1990, 2000, 2010, and 2018, at a spatial resolution of $30 \mathrm{~m} \times 30 \mathrm{~m}$, were provided from the Resource and Environment Data Cloud Platform (http://www.resdc.cn/Default.aspx) and were based on Landsat TM/ETM + remote sensing images from multiple dates. The land use data were classified into six types: cultivated land, forest, grassland, water area, built-up area, and unused land. Two nighttime light imagery datasets, DMSP/OLS and NPP/VIIRS (https://www.ngdc.noaa.gov/eog/index.html), were used to quantify the urbanization of the study area. The raster data for populations in 1990, 2000, 2010, and 2015 were also obtained from the Resource and Environment Data Cloud Platform. The vector data for urban boundaries were obtained from the National Earth System Science Data Sharing Infrastructure, National Science \& Technology Infrastructure of China (http://www.geodata.cn).

\subsection{Classification of Urbanization}

DMSP/OLS data became available in 1992, but the land use data used in this study began in 1990. Therefore, the DMSP/OLS data for 1992 were used to approximate the land use data in 1990. Additionally, DMSP/OLS data were terminated in 2013. Since 2012, NPP/VIIRS data, which are based on stronger night light detection capability, have been widely used and have become the successor to DMSP/OLS. However, there are differences in the properties of the satellite sensors, spatial resolutions and spectral response modes between the two types of data. Referring to the study of Li et al. [54], we evaluated urbanization in 2010-2018 based on the fused DMSP/OLS and NPP/VIIRS data. The main steps are as follows: we first conducted radiometric calibrations and interannual series corrections on the DMSP/OLS data, then, we established a regression relationship between DMSP/OLS and NPP/VIIRS data in 2013, and finally, we used NPP/VIIRS data fitting to generate the simulated DMSP/OLS data for 2014-2018.

Digital numbers (DNs) of nighttime light imagery data were used to analyze and reveal urban expansion from 1992-2018. Higher DN values indicate higher levels of urbanization. The study area was divided into three urbanization levels: developed urban, developing urban, and rural. Referring to the study of Li et al. [55], we determined the urbanization levels as follows (Table 1).

Table 1. Conditions for dividing different urbanization level zones by the ranges of DN values.

\begin{tabular}{cc}
\hline Conditions & Urbanization Levels \\
\hline$D N_{1992}$ value $\geq 50$ and $D N_{2018}$ value $\geq 50$, & Developed urban area \\
$D N_{1992}$ value $<50$ and $D N_{2018}$ value $\geq 50$, & Developing urban area \\
$D N_{1992}$ value $<50$ and $D N_{2018}$ value $<50$, & Rural area \\
\hline
\end{tabular}

Moreover, based on statistical analysis in ArcGIS 10.2, we analyzed the variations in population totals and the proportions of developed urban, developing urban and rural areas for different periods, as these can reveal the immigration and emigration of people and further determine the different urbanization stages in the Su-Xi-Chang region.

\subsection{Detection of Land Use Changes}

To explore the temporal changes in land use, the areas (ha) of different land-use types were calculated, and the increasing or decreasing quantities of each type were compared and specified. Moreover, we used the change rates in land-use types to represent the change trends of different land-use types in a certain period. The calculation is as follows:

$$
R_{L}=\frac{U_{b}-U_{a}}{U_{a}}
$$


where $R_{L}$ represents the change rate in one land use type and is expressed in $\%, U_{a}$ and $U_{b}$ are the areas of this land-use type in the early and late stages of the research period, respectively.

Spatial overlay analysis in ArcGIS 10.2 was used to detect the spatial changes in land use.

\subsection{Assessment of Carbon Storage}

In this study, the InVEST model was used to simulate the change in carbon stocks in response to urbanization. Carbon stock refers to the quantity of carbon stored in a carbon pool at a specified time. The InVEST model divides the ecosystem carbon stock into four basic carbon pools: aboveground biomass, belowground biomass, soil organic matter, and dead organic matter. Aboveground biomass includes all living plant materials above the soil (e.g., bark, trunk, branches, and leaves), belowground biomass refers to the living root systems of the aboveground biomass, soil organic matter represents the organic component of soil, which is the largest terrestrial carbon pool, dead organic matter includes litter as well as lying and standing deadwood [29]. InVEST is a geospatial modeling framework tool that can aggregate the biophysical amount of carbon stored in these four carbon pools [56]. The input data required for the operation of the carbon storage and sequestration module of the InVEST model include the land use maps of the study area and the carbon densities of different land-use types [29]. Taking land use type as an evaluation unit, the amount of carbon storage is calculated by multiplying the carbon stock of each land-use type per unit area by its area. The calculations are as follows:

$$
\begin{gathered}
C_{i}=C_{i-\text { above }}+C_{i-\text { below }}+C_{i-\text { soil }}+C_{i-\text { dead }} \\
C_{\text {total }}=\sum_{i=1}^{6} C_{i} \times S_{i}
\end{gathered}
$$

where $i$ is a certain type of land use, $C_{i-a b o v e}, C_{i-\text { below }}, C_{i-\text { soil }}$, and $C_{i-\text { dead }}$ represent the aboveground carbon density, belowground carbon density, soil organic matter carbon density, and dead organic matter carbon density, respectively. $C_{i}$ is the carbon stock for a certain type of land use, $C_{\text {total }}$ is the total amount of carbon storage, and $S_{i}$ is the area of a certain land-use type $i$.

Due to limited time and funding, the carbon density data in this study were derived from the results of several local studies and not from actual measurements. However, because carbon density values vary according to climate, soil properties, and land use, we referred to the carbon density values in studies conducted in or near the Su-Xi-Chang region. Referring to the study of Guo et al., which conducted a carbon storage assessment in the Yangtze River city group using the field survey method [57], we obtained the mean aboveground, belowground, and soil organic matter carbon densities of different land-use types (Table 2). Since no previous studies have measured the dead organic matter carbon density in or near the Su-Xi-Chang region, this parameter was determined by referring to the study of Tang et al., which estimated the carbon pools in China's terrestrial ecosystems based on an intensive field survey [58].

Table 2. Mean carbon densities for each land-use type in the Su-Xi-Chang region (Mg C/ha).

\begin{tabular}{lccccc}
\hline \multicolumn{1}{c}{ Land Use Types } & $C_{\text {i-above }}$ & $\boldsymbol{C}_{\text {i-below }}$ & $\boldsymbol{C}_{\boldsymbol{i} \text {-soil }}$ & $\boldsymbol{C}_{\boldsymbol{i} \text {-dead }}$ & Sources \\
\hline Cultivated land & 13.1 & 2.5 & 35.0 & 0 & {$[57,58]$} \\
Forest & 19.4 & 3.9 & 35.7 & 1.9 & {$[57,58]$} \\
Grassland & 2.1 & 9 & 34.5 & 0.1 & {$[57,58]$} \\
Water area & 0.6 & 0 & 38.5 & 0 & {$[57,58]$} \\
Built-up area & 1.1 & 0 & 37.3 & 0 & {$[57,58]$} \\
Unused land & 0.1 & 0 & 34.6 & 0 & {$[57,58]$} \\
\hline
\end{tabular}

\section{Results}

\subsection{Urbanization in the Su-Xi-Chang Region}

The mean DN values in the study area were 9.32, 11.98, 37.37 and 39.43 in 1992, 2000, 2010, and 2018 , respectively, showing an increase of more than four times. The mean DN value of the developed 
urban areas (62.82) was larger than that of the developing urban areas (51.44) and larger than that for the rural areas (21.91) in 2018 (Figure 2). From 1992 to 2018, urban expansion accounted for $46.35 \%$ of the total area of the study area. During the periods of 1992-2000, 2000-2010, and 2010-2018, the areas of urban expansion were $2.79 \times 10^{4}, 7.23 \times 10^{5}$, and $1.45 \times 10^{5}$ ha, respectively.

From 1990 to 2000, the total population of the entire study area showed an increasing trend. However, the proportion of the population in the developed urban areas increased, while that in the other two areas decreased (Table 3). From 2000-2010, the trend of population growth continued: the proportion of the population in developing urban areas increased significantly and that of the other two areas decreased. After 2010, both the total number and the proportion of the population in the developed urban areas showed a decreasing trend, while these two indicators both increased in the developing urban areas and rural areas. Based on the law of population migration, our study classified these three periods as the different stages of urbanization: the initially urbanizing stage, the rapidly urbanizing stage, and the highly urbanized stage.

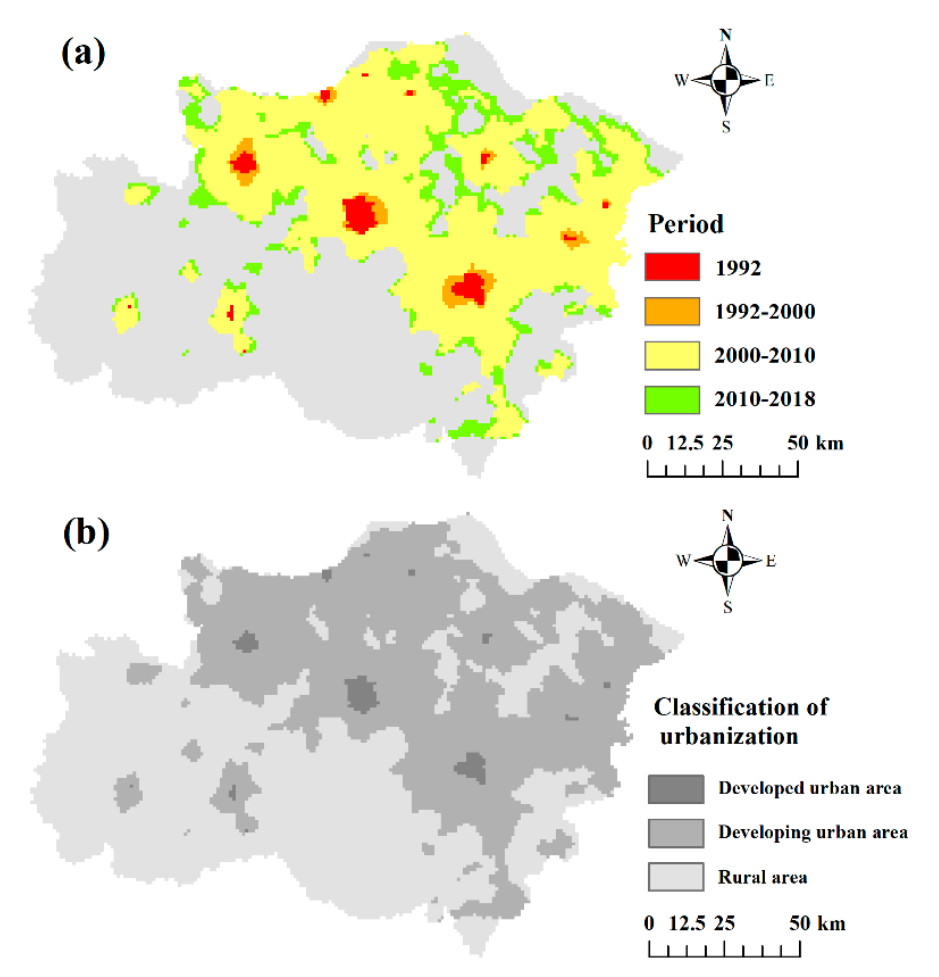

Figure 2. (a) Processes of urban expansion from 1992-2018 (different colors represent regions where the DN values were 50 or greater, indicating urban expansion.), (b) Areas with different levels of urbanization (see Table 1 for the division basis).

Table 3. Population of areas with different urbanization levels (Unit: ten thousand).

\begin{tabular}{ccccccccc}
\hline & $\mathbf{1 9 9 0}$ & Proportion & $\mathbf{2 0 0 0}$ & Proportion & $\mathbf{2 0 1 0}$ & Proportion & $\mathbf{2 0 1 5}$ & Proportion \\
\hline Developed urban area & 70.90 & $6 \%$ & 161.14 & $10 \%$ & 179.13 & $8 \%$ & 141.07 & $6 \%$ \\
Developing urban area & 729.17 & $57 \%$ & 881.02 & $56 \%$ & 1354.49 & $63 \%$ & 1412.05 & $64 \%$ \\
Rural area & 447.33 & $37 \%$ & 524.57 & $33 \%$ & 623.29 & $29 \%$ & 667.82 & $30 \%$ \\
Total & 1274.40 & & 1566.74 & & 2156.91 & & 2220.95 & \\
\hline
\end{tabular}

\subsection{Land Use Changes}

From 1990 to 2018, the number of cultivated lands and built-up areas changed substantially, followed by the number of water areas, while the other land-use types changed only marginally (Figure 3). The total area of cultivated land showed a continuously decreasing trend $\left(410.92 \times 10^{3} \mathrm{ha}\right)$, and the largest change rate (23.70\%) occurred from 2000-2010. From 1990-2018, the decrease in the 
area of cultivated land in the developed urban areas, developing urban areas, and rural areas was $7.42 \times 10^{3}, 330.89 \times 10^{3}$, and $72.40 \times 10^{3}$ ha, accounting for $1.81 \%, 80.57 \%$, and $17.63 \%$ of the total, respectively. The amount of built-up area tended to increase continuously $\left(387.13 \times 10^{3} \mathrm{ha}\right)$, and its change rate reached a maximum of $86.31 \%$ in the period from $2000-2010$. During the period from 1990-2018, the built-up area in the developed urban areas, developing urban areas, and rural areas increased by $7.60 \times 10^{3}, 327.90 \times 10^{3}$, and $51.64 \times 10^{3}$ ha, accounting for $1.85 \%, 79.84 \%$, and $12.57 \%$ of the total, respectively. The water area showed a trend of first increasing and then decreasing, but the area fluctuated little. The areas of forest, grassland, and unused land changed slowly by $5.07 \times 10^{3}$, $6.46 \times 10^{3}$, and $2.87 \times 10^{3}$ ha, respectively.
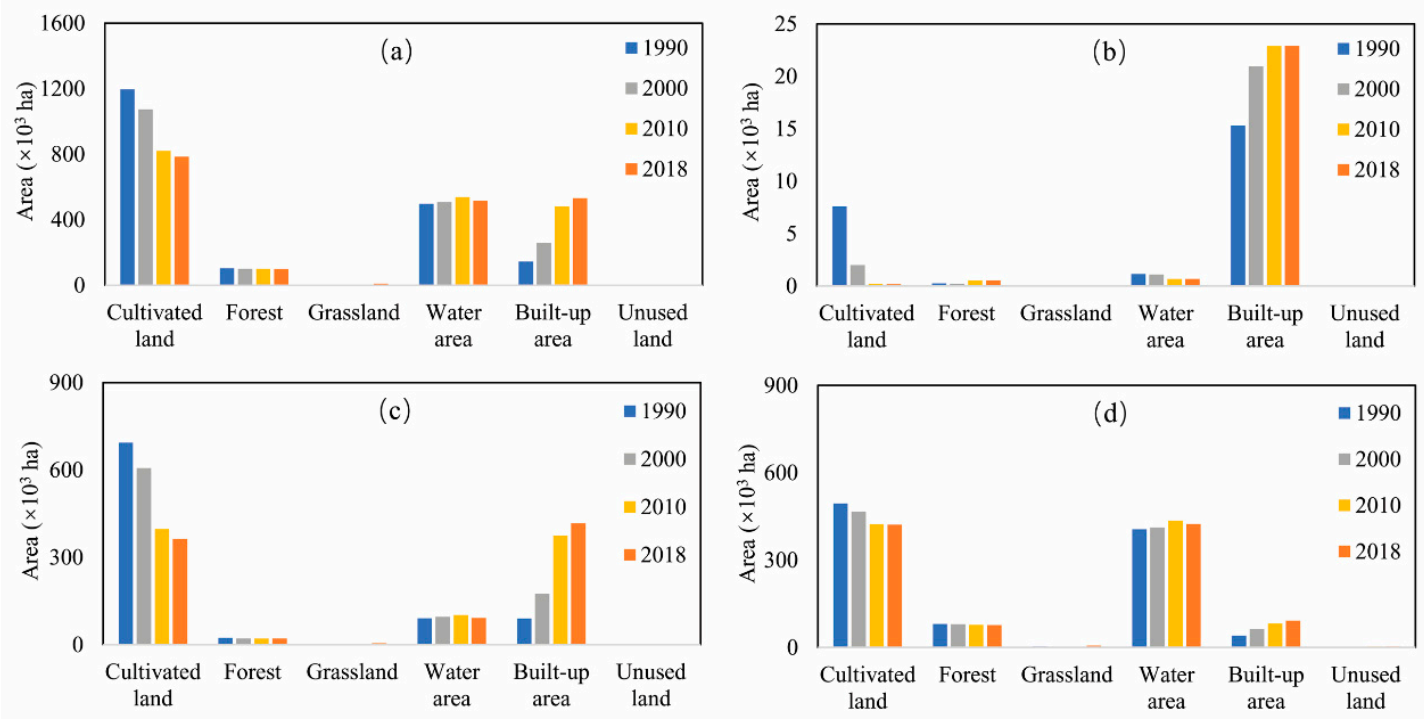

Figure 3. Quantitative changes in different land-use types from 1990-2018. (a) The whole study area,

(b) Developed urban area, (c) Developing urban area, (d) Rural area.

As seen from the spatial distributions and transition matrix of land-use changes (Figure 4, Tables 4-6), cultivated land, built-up areas, and water areas changed significantly, while the other land-use types changed only slightly during the study period. From 1990 to 2000, much of the cultivated land was converted to built-up areas in developing urban areas, which were radially distributed around the city center, the conversion of cultivated land to water area was scattered in Changzhou and Suzhou. During this period, the urbanization of the study area was just beginning, and the land-use changes were dominated by an increase in built-up areas (mainly industrial lands and residential lands) and water areas (mainly aquacultural lands). In terms of the increased area of the built-up land, the development levels of Suzhou, Wuxi, and Changzhou were similar.

From 2000-2010, the conversion of cultivated lands to built-up areas occurred in many parts of the Su-Xi-Chang region, indicating that urbanization had developed rapidly during this period. When comparing the increasing built-up areas of different cities, we see that Suzhou $\left(13.47 \times 10^{4}\right.$ ha $)>$ Wuxi $\left(5.63 \times 10^{4}\right.$ ha $)>$ Changzhou $\left(3.83 \times 10^{4}\right.$ ha $)$, showing that Suzhou had a faster urbanization process. The conversion of cultivated lands to water areas mainly occurred in the developing urban areas and rural areas of Changzhou and Suzhou, the conversion of water areas to built-up areas mainly occurred in the developing urban areas of Wuxi and Suzhou. Around the city center of Wuxi, some cultivated land was converted into the forest, which may be related to the ecological protection policy in force during this period.

From 2010-2018, the conversion of cultivated land to built-up areas was still the main land-use change, but the converted area was much less than that from 1990-2000 or 2000-2010. In this period, the urbanization process slowed dramatically. In addition to the increase in built-up area, there was a considerable increase in cultivated land and grassland. Some built-up areas (mostly abandoned 
industrial land and rural residential land) were converted into cultivated land in the northeastern part of the study area, which is far from the city center of Suzhou and near the Yangtze River. Compared to the other two cities, the land-use changes for Suzhou in this period were more diversified.

(a)

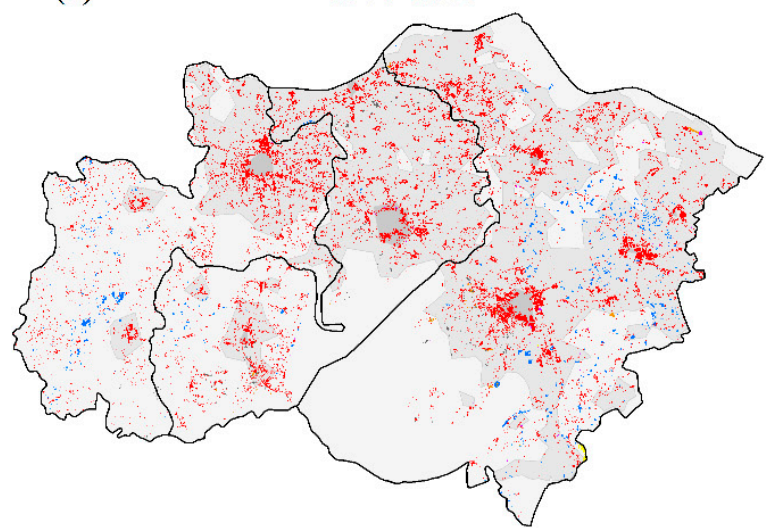

(c)

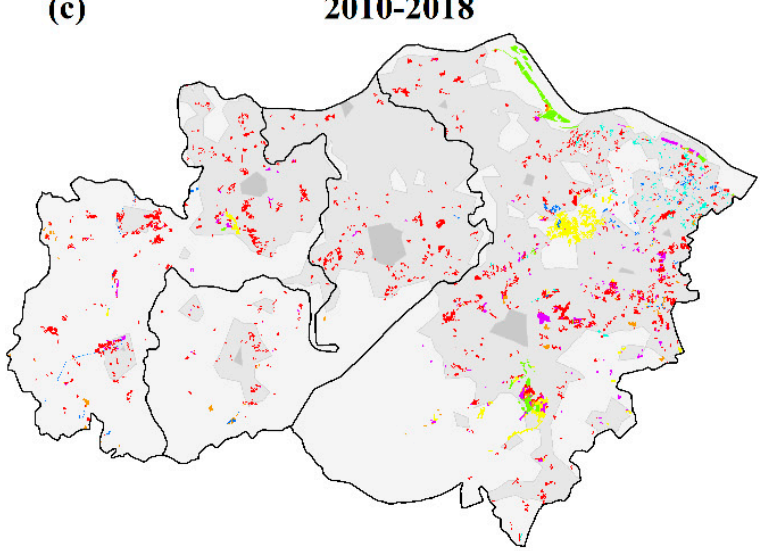

(b)

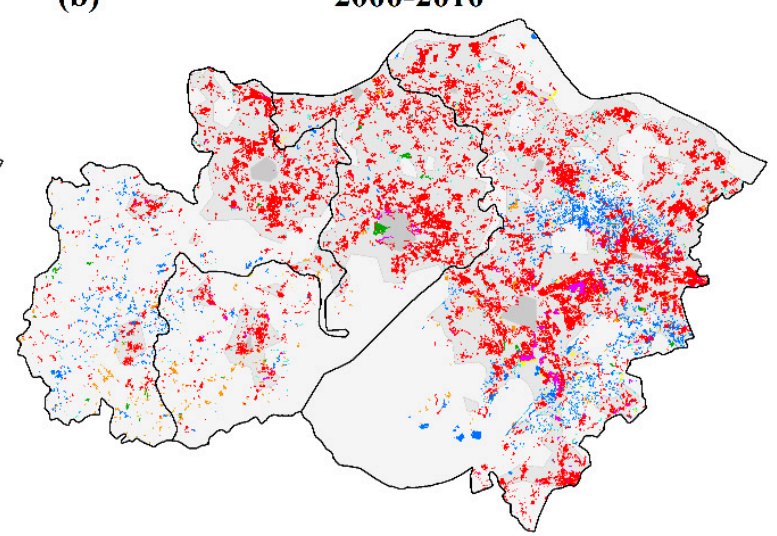

Figure 4. Spatial distribution of land-use changes from (a) 1990-2000, (b) 2000-2010, and (c) 2010-2018.

Table 4. Transition matrix of land-use change during 1990-2000 (ha).

\begin{tabular}{ccccccccc}
\hline \multirow{2}{*}{ Land Use } & \multicolumn{7}{c}{$\mathbf{2 0 0 0}$} \\
\cline { 2 - 9 } & $\begin{array}{c}\text { Cultivated } \\
\text { Land }\end{array}$ & Forest & Grassland & $\begin{array}{c}\text { Water } \\
\text { Area }\end{array}$ & $\begin{array}{c}\text { Built-Up } \\
\text { Area }\end{array}$ & $\begin{array}{c}\text { Unused } \\
\text { Land }\end{array}$ & $\begin{array}{c}\text { Transfer-Out } \\
\text { Area }\end{array}$ \\
\hline $\begin{array}{c}\text { Cultivated } \\
\text { land }\end{array}$ & $1,038,847$ & 5177 & 234 & 23,395 & 127,338 & 21 & 156,165 \\
\cline { 2 - 9 } & Forest & 4638 & 94,579 & 104 & 704 & 3117 & 124 & 8687 \\
\cline { 2 - 9 } & Grassland & 204 & 68 & 3873 & 280 & 159 & 2 & 713 \\
\cline { 2 - 9 } & Water area & 11,723 & 610 & 406 & 481,568 & 1973 & 28 & 14,740 \\
\cline { 2 - 9 } & Built-up area & 18,688 & 471 & 20 & 854 & 125,072 & 4 & 20,037 \\
\cline { 2 - 9 } & Unused land & 24 & 27 & 3 & 54 & 19 & 625 & 127 \\
\hline & $\begin{array}{c}\text { Transfer-in } \\
\text { area }\end{array}$ & 35,277 & 6353 & 767 & 25,287 & 132,606 & 179 & - \\
\hline
\end{tabular}


Table 5. Transition matrix of land-use change from 2000-2010 (ha).

\begin{tabular}{ccccccccc}
\hline \multirow{2}{*}{ Land Use } & \multicolumn{7}{c}{$\mathbf{2 0 1 0}$} \\
\cline { 2 - 9 } & $\begin{array}{c}\text { Cultivated } \\
\text { Land }\end{array}$ & Forest & Grassland & $\begin{array}{c}\text { Water } \\
\text { Area }\end{array}$ & $\begin{array}{c}\text { Built-up } \\
\text { Area }\end{array}$ & $\begin{array}{c}\text { Unused } \\
\text { Land }\end{array}$ & $\begin{array}{c}\text { Transfer-Out } \\
\text { Area }\end{array}$ \\
\hline $\begin{array}{c}\text { Cultivated } \\
\text { land }\end{array}$ & 810,139 & 3125 & 25 & 40,403 & 219,412 & 1379 & 264,344 \\
\cline { 2 - 9 } 2000 & Forest & 550 & 96,208 & 0 & 432 & 2012 & 1900 & 4894 \\
\cline { 2 - 9 } & Grassland & 85 & 10 & 3596 & 595 & 237 & 117 & 1044 \\
\cline { 2 - 9 } & Water area & 3052 & 42 & 51 & 494,152 & 9914 & 1 & 13,060 \\
\cline { 2 - 9 } & Built-up area & 5993 & 257 & 1 & 2595 & 248,444 & 410 & 9256 \\
\cline { 2 - 9 } & Unused land & 0 & 42 & 0 & 29 & 94 & 643 & 165 \\
\hline & $\begin{array}{c}\text { Transfer-in } \\
\text { area }\end{array}$ & 9680 & 3476 & 77 & 44,054 & 231,669 & 3807 & - \\
\hline
\end{tabular}

Table 6. Transition matrix of land-use change during 2010-2018 (ha).

\begin{tabular}{|c|c|c|c|c|c|c|c|c|}
\hline & \multirow{2}{*}{ Land Use } & \multicolumn{7}{|c|}{2018} \\
\hline & & $\begin{array}{l}\text { Cultivated } \\
\text { Land }\end{array}$ & Forest & Grassland & $\begin{array}{l}\text { Water } \\
\text { Area }\end{array}$ & $\begin{array}{c}\text { Built-Up } \\
\text { Area }\end{array}$ & $\begin{array}{c}\text { Unused } \\
\text { Land }\end{array}$ & $\begin{array}{c}\text { Transfer-Out } \\
\text { Area }\end{array}$ \\
\hline \multirow{7}{*}{2010} & $\begin{array}{c}\text { Cultivated } \\
\text { land }\end{array}$ & 769,440 & 0 & 387 & 2680 & 47,263 & 49 & 50,379 \\
\hline & Forest & 16 & 98,493 & 375 & 108 & 679 & 13 & 1191 \\
\hline & Grassland & 145 & 0 & 3233 & 47 & 248 & 0 & 440 \\
\hline & Water area & 11,495 & 0 & 6830 & 512,206 & 7646 & 29 & 26,000 \\
\hline & Built-up area & 3694 & 0 & 185 & 506 & 475,728 & 0 & 4385 \\
\hline & Unused land & 123 & 0 & 40 & 44 & 714 & 3529 & 921 \\
\hline & $\begin{array}{c}\text { Transfer-in } \\
\text { area }\end{array}$ & 15,473 & 0 & 7817 & 3385 & 56,550 & 91 & - \\
\hline
\end{tabular}

\subsection{Carbon Storage Changes}

\subsubsection{Changes in the Amount of Carbon Storage from 1990-2018}

Over the past 28 years, carbon storage in the entire study area has been continuously decreasing (Table 7). During the period from 2000-2010, carbon storage decreased by $3.14 \mathrm{Tg}$ C, which was 2.08 and 7.85 times that for the corresponding amounts between 1990-2000 and 2010-2018, respectively $\left(1 \mathrm{Tg} \mathrm{C}=10^{6} \mathrm{tC}\right)$. This indicates that the rapid urbanization from 2000 to $2010 \mathrm{had}$ a strong negative impact on carbon storage. Among the three cities, the largest carbon stock losses over the past 28 years occurred in Suzhou, followed by Wuxi and Changzhou. Although the increase in a built-up area in the three cities was similar between 1990 and 2000, the carbon storage reduction in Suzhou was greater than that in Wuxi and Changzhou. This gap continued to widen between 2000 and 2010. It is worth noting that although the increase in built-up area in Suzhou was twice that of Changzhou, the reduction in carbon storage in Suzhou was less than that in Changzhou.

Table 7. Quantitative changes in carbon storage during 1990-2018 (Tg C).

\begin{tabular}{cccccccc}
\hline & $\mathbf{1 9 9 0}$ & $\mathbf{2 0 0 0}$ & $\mathbf{2 0 1 0}$ & $\mathbf{2 0 1 8}$ & $\mathbf{1 9 9 0 - 2 0 0 0}$ & $\mathbf{2 0 0 0 - 2 0 1 0}$ & $\mathbf{2 0 1 0 - 2 0 1 8}$ \\
\hline Whole study area & 91.97 & 90.46 & 87.32 & 86.92 & -1.51 & -3.14 & -0.40 \\
Suzhou & 44.12 & 43.40 & 41.55 & 41.41 & -0.72 & -1.85 & -0.14 \\
Wuxi & 24.33 & 23.90 & 23.20 & 23.10 & -0.43 & -0.70 & -0.10 \\
Changzhou & 23.52 & 23.16 & 22.57 & 22.41 & -0.36 & -0.59 & -0.16 \\
\hline
\end{tabular}




\subsubsection{Spatial Heterogeneity of Carbon Storage Changes}

From 1990-2000, carbon stock losses were widely distributed in the study area and were characterized by being more concentrated near the city centers and more dispersed near rural areas (Figure 5). This is consistent with the spatial distribution of built-up area increases during this period (Figure 4a). From 2000-2010, the area of carbon storage reduction further increased and was distributed in most areas except for Taihu Lake and the mountainous areas in the south. Compared to the previous period, the reduction in carbon storage in many areas changed from sporadic distributions to planar aggregation distributions. Additionally, there were a few areas with carbon storage increases occurring around the urban centers of Wuxi and Suzhou. From 2010-2018, there were significantly fewer areas with carbon stock losses than in the previous period, indicating that the urbanization process slowed down in this period. It is noteworthy that increases in carbon storage occurred in the central and southern parts of Suzhou and along the Yangtze River in the north.

(a)

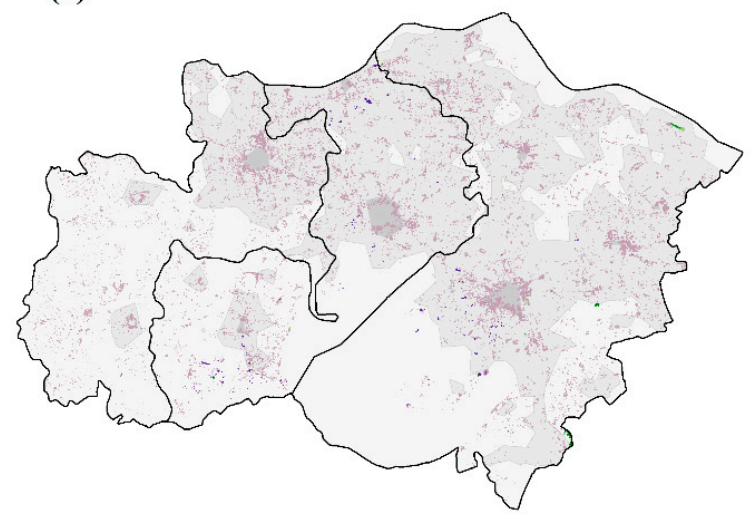

(c)

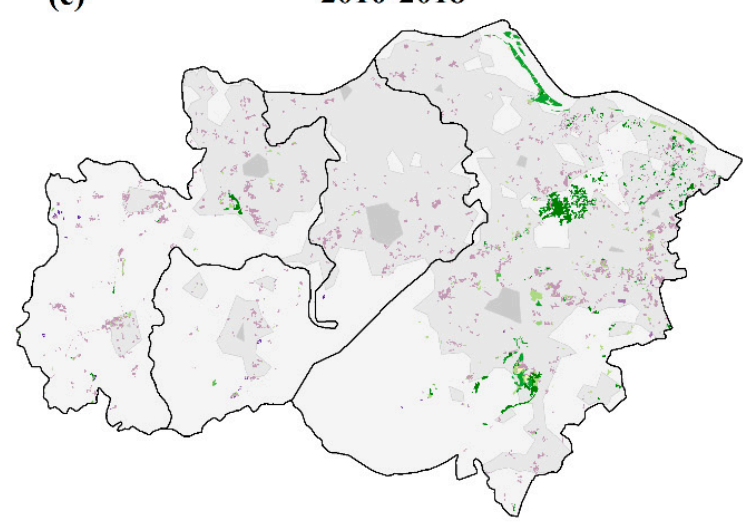

(b)

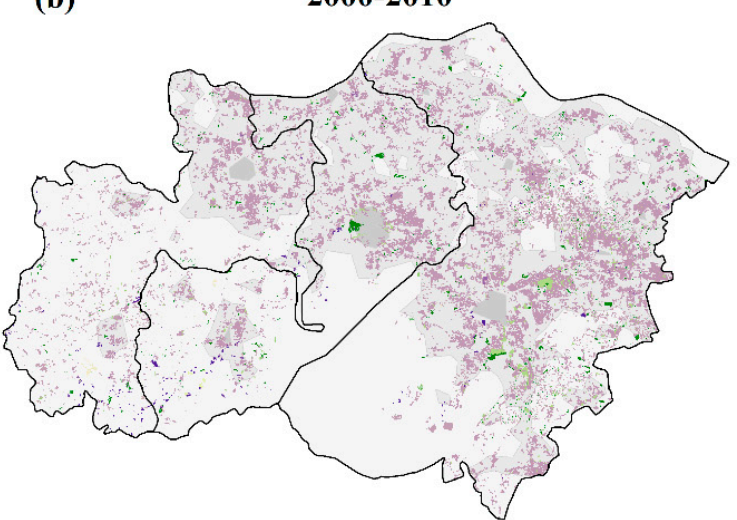

Changes in carbon storage

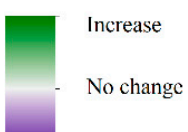

Decline

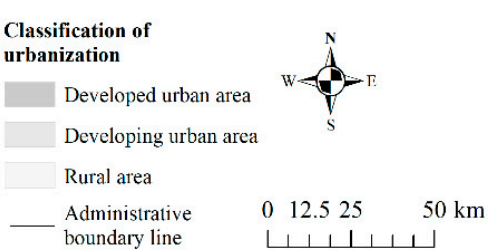

Figure 5. Spatial distribution of the changes in carbon storage from (a) 1990-2000, (b) 2000-2010, and (c) 2010-2018.

The spatial heterogeneity of carbon storage changes is also reflected in regions with different urbanization levels (Figure 6). Carbon storage in the study area decreased the most in the developing urban areas, followed by rural areas and developed urban areas. From 1990-2018, carbon stock losses in the developing areas of Suzhou, Wuxi, and Changzhou were 2.39, 0.98, and $0.68 \mathrm{Tg} \mathrm{C}$, representing $88.04 \%, 79.65 \%$, and $61.20 \%$ of the total in each city, respectively. In addition, the carbon stock losses in rural areas were also large, especially in Changzhou, whose carbon storage has decreased by $0.43 \mathrm{Tg} \mathrm{C}$ over the past 28 years. It should be noted that carbon storage in the rural areas of Suzhou increased by $0.09 \mathrm{Tg} C$ from 2010-2018. Among the three different urbanization regions, the developed urban areas have the lowest carbon stock losses. In general, the ratio of carbon stock loss in developed urban areas, developing urban areas, and rural areas of the study area were 1:48:11. In addition, the carbon 
storage of the study area decreased most from 2000 to 2010, which is also true for Suzhou, Wuxi, and Changzhou. For example, the total reduction in carbon storage for Suzhou from 2000-2010 (1.85 Tg C) was 2.55 and 13.17 times that for the periods of 1990-2000 and 2010-2018, respectively.
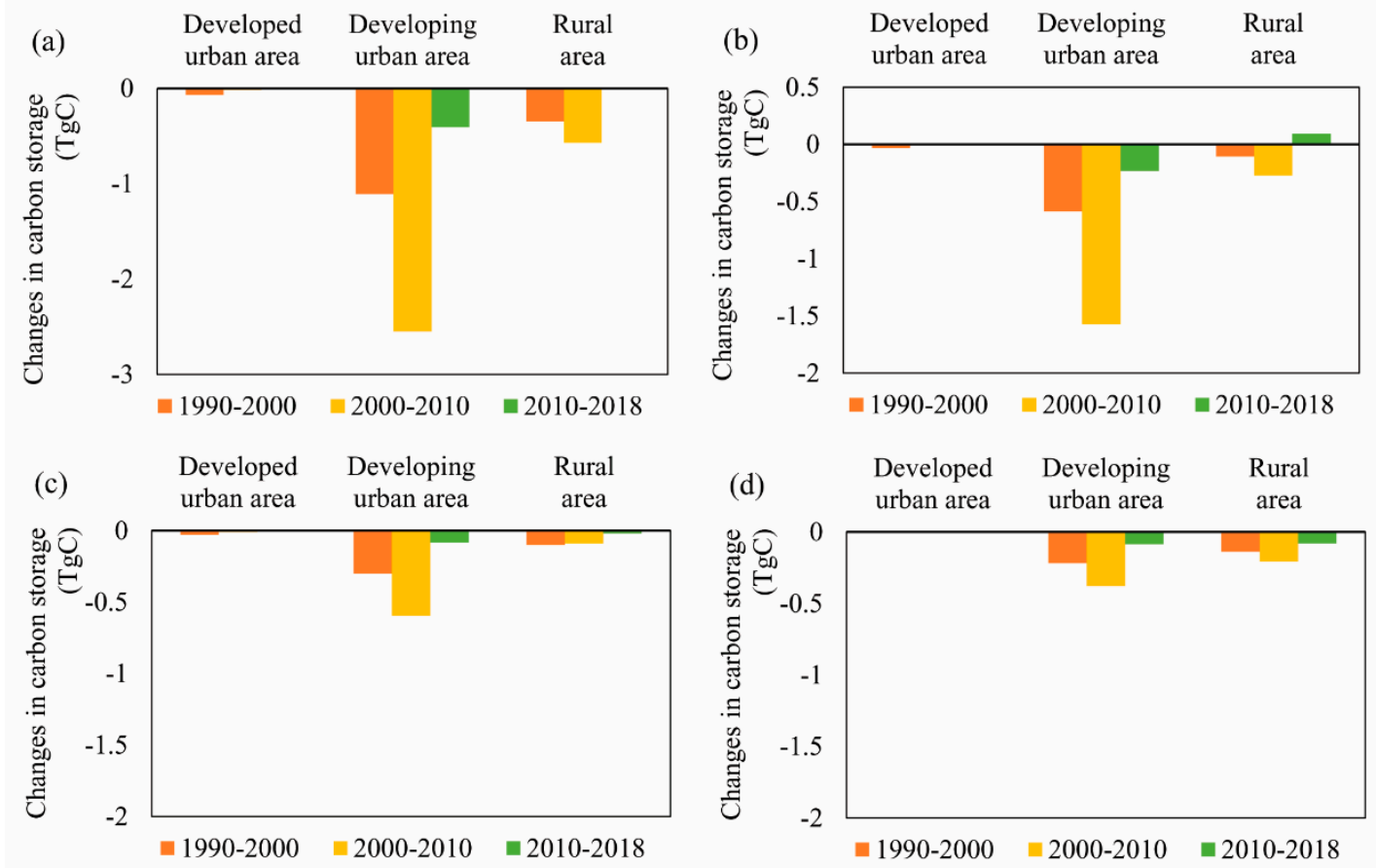

Figure 6. Carbon storage changes in areas with different urbanization levels for (a) the whole study area, (b) Suzhou, (c) Wuxi, and (d) Changzhou.

\subsection{Influence of Land Use Change on Carbon Storage}

As seen from the statistical analyses (Tables 8-10), the decrease in cultivated land has been the largest continuous cause of carbon stock loss over the past 28 years. Due to the urbanization process in the study area, many unbuilt areas were forced to convert to built-up areas. Among them, the conversion from cultivated lands to built-up areas accounted for the largest proportion, followed by conversions from water areas and forests, which mainly occurred in developing urban areas (Figure 4). For the periods from 1990-2000 and 2000-2010, much-cultivated land in the rural areas was converted to water areas, also resulting in a large amount of carbon stock loss. In addition, land-use changes can also lead to increases in carbon storage. After 2000, for example, the conversion of built-up areas and water areas to cultivated land, of cultivated lands to forests, and of water areas to grasslands resulted in considerable growth in carbon storage.

Table 8. The effects of the conversion of the main land-use types on carbon storage during 1990-2000.

\begin{tabular}{ccc}
\hline Land Use Type Conversion & Area $\left(\mathbf{1 0}^{\mathbf{7}} \mathbf{h a )}\right.$ & Changes in Carbon Storage (Gg C) \\
\hline Cultivated land to built-up area & 109.49 & -1334.51 \\
Cultivated land to water area & 11.45 & -131.57 \\
Forest to built-up area & 2.44 & -54.90 \\
Water area to built-up area & 0.60 & -0.42 \\
Water area to cultivated land & 0.43 & 4.94 \\
\hline
\end{tabular}


Table 9. The effects of the conversion of the main land-use types on carbon storage from 2000-2010.

\begin{tabular}{ccc}
\hline Land Use Type Conversion & Area $\left(\mathbf{1 0}^{\mathbf{7}} \mathbf{h a )}\right.$ & Changes in Carbon Storage (Gg C) \\
\hline Cultivated land to built-up area & 219.41 & -2674.41 \\
Cultivated land to water area & 40.40 & -464.19 \\
Water area to built-up area & 9.91 & -6.94 \\
Built-up area to cultivated land & 5.99 & 73.05 \\
Cultivated land to forest & 3.13 & 32.16 \\
Water area to cultivated land & 3.05 & 35.06 \\
\hline
\end{tabular}

Table 10. The effects of the conversion of the main land-use types on carbon storage during 2010-2018.

\begin{tabular}{|c|c|c|}
\hline Land Use Type Conversion & Area $\left(10^{7}\right.$ ha $)$ & Changes in Carbon Storage (Gg C) \\
\hline Cultivated land to built-up area & 47.26 & -576.08 \\
\hline Water area to cultivated land & 11.50 & 132.07 \\
\hline Water area to built-up area & 7.65 & -5.35 \\
\hline Water area to grassland & 6.83 & 45.28 \\
\hline Built-up area to cultivated land & 3.69 & 45.01 \\
\hline Cultivated land to water area & 2.68 & -30.79 \\
\hline
\end{tabular}

\section{Discussion}

Urbanization brings population and economic growth, but it also leads to ecological problems [43-45]. Many studies have shown that urbanization has an impact on carbon storage in terrestrial ecosystems [36-41]. In contrast to previous studies, this study comprehensively analyzes the "spatial" and "temporal" changes in carbon stocks from the urbanization process. In this section, the results from the study area are analyzed in conjunction with China's development policy and are compared with the findings for cities examined in other studies. The issues we tried to discuss were threefold: (1) to theoretically determine if there are regularities in carbon storage changes in time and space through the process of urbanization, (2) to discuss the pros and cons among different carbon stock modeling approaches, and (3) to provide practical inspiration and suggestions for sustainable urban development.

\subsection{Spatiotemporal Changes in Carbon Storage Due to Urbanization}

In this study, we found that the maximum carbon stock losses occurred in the developing urban areas (Figures 5-7). This result is consistent with the results of [41,55]. In locations characterized by rapid urbanization, the increase in the built-up area occurs at the cost of occupying other land use types, such as cultivated land, water, and forest $[59,60]$. The area of the urban centers is limited, and the increase in built-up areas tends to extend outward from developed urban areas, so carbon storage decreased the most in developing urban areas. This finding is consistent with a study conducted in the Seattle metropolitan region that argued that the increase in built-up area was the most important reason for the carbon stock losses [61]. In addition, carbon stock losses were also high in rural areas (Figures 5-7) because, unlike in Beijing and Shanghai, whose urbanization benefits from sustained investment by the country, the urbanization in the Su-Xi-Chang region belongs to the bottom-up model. This development model reflects rural enterprises achieving urbanization through rural industrialization [62]. Rural enterprises occupy a large amount of cultivated land due to a lack of planning, which leads to reductions in carbon storage. The developed urban areas were saturated at the beginning of the research period, hence, little change in carbon storage was detected. Some studies have explored the spatial distribution characteristics of carbon storage in urban-rural gradients, but they were static studies only focused on a specific time [33,34]. It is difficult to obtain information about the trends and reasons for carbon stock changes from this research stream. In contrast, this study analyzed the dynamic changes in carbon storage in areas at different urbanization levels, which can provide more references for decision-making. 

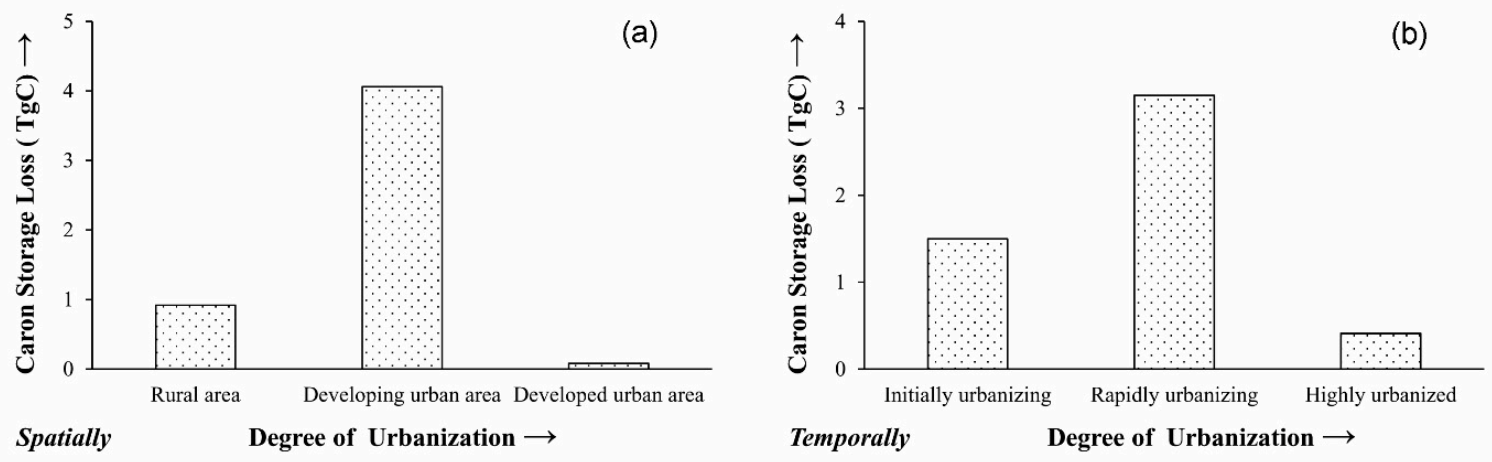

Figure 7. The regularities of spatiotemporal changes in carbon storage in response to urbanization. Vertical axis: the amount of carbon storage loss. Horizontal axis: the degree of urbanization in (a) space and (b) time.

The temporal variations in carbon storage during the urbanization process are similar to those obtained from spatial analysis. Carbon storage declined most in the rapidly urbanizing stage (2000-2010), followed by the initially urbanizing stage (1990-2000) and the highly urbanized stage (2010-2018). In the initially urbanizing stage (1990-2000), many migrants, as well as those who originally lived in the suburbs and villages, were attracted to the city centers for better job opportunities and quality of life (Table 2). In addition, this was also the economic development period of the "Sunan model". Rural enterprises mushroomed, constantly being established and developed during this period. Therefore, built-up areas increased by spreading around the urban centers and appearing sporadically in rural areas. These changes reduced carbon storage to a certain extent. The maximum carbon stock loss occurred in the rapidly urbanizing stage (2000-2010), which is consistent with the results of [14]. During this period, the built-up areas increased by spreading outside the city centers, resulting in substantial reductions in carbon storage. The increase in the built-up areas in this period was mainly due to three reasons: (1) with the popularity of highways and private cars, cities spread farther into the suburbs, (2) to obtain greater economic benefits, factories tended to cluster together, which required more land to build factories and ancillary facilities, and (3) the increase in urban populations and the desire to improve living conditions led to the construction of large numbers of urban houses. In the highly urbanized stage (2010-2018), there was no more space for urban development. Moreover, as the environmental problems caused by disorganized long-term development became increasingly prominent, the government began to pay attention to cultivated land and environmental protection, so the carbon stock loss in this period was minimal.

\subsection{Comparison of Assessment Methods}

In addition to the InVEST model, field surveys, remote sensing, and the Carnegie-Ames-Stanford approach (CASA) model have been used in many studies for carbon storage assessment. Field survey data are of great significance for parameter calibration in model evaluation and for verification of remote sensing results $[12,63]$. However, field surveys take a great deal of time and manpower, so they are often used in single ecosystems, such as grassland and soil carbon pool [14]. In addition, some studies use remote sensing data and the CASA model to assess carbon storage $[25,26]$. Since remote sensing data can reflect the actual growth of vegetation, this method can obtain more accurate results and reflect the spatial heterogeneity of carbon reserves in each land-use type. However, this method also has shortcomings. For example, the evaluation results of the CASA model can only reveal carbon stocks in aboveground biomass but not in belowground biomass, soil, or dead organic matter. Moreover, running the CASA model requires extensive remote sensing, vegetation, and meteorological data and parameters, making it less operable than the InVEST model. In contrast, the InVEST model is able to assess carbon stocks based only on the land use types map and carbon densities for the four-carbon pools, which is a much simpler and more convenient approach. Many recent studies have 
shown that the InVEST model offers advantages for studying the relationship between land use and carbon stocks and can produce reliable results $[8,14,23,40,41]$.

\subsection{Implications}

Our study investigated the impacts of land-use changes on carbon storage in the Su-Xi-Chang region. The results showed that the decrease in cultivated land was the main reason for the carbon stock loss, which is consistent with previous studies of $[23,64]$. We found that the expansion of built-up areas in developing urban areas and the development of aquaculture in rural areas resulted in significant reductions in carbon storage. Unlike previous studies, we found that the conversion of cultivated lands to forests in developed urban areas, the conversion of built-up areas to cultivated lands in developing urban areas, and the conversion of water areas to cultivated lands and grasslands in rural areas can enhance carbon storage. Based on our findings (Figure 8), some recommendations for mitigating the carbon stock losses in the Su-Xi-Chang region are proposed. (1) Due to its small area, the developed urban areas are not suitable for agriculture. We suggest planting trees on plots that are not suitable for farming, for example, establishing urban forest parks, to increase carbon storage in these areas. (2) In developing urban areas, a policy for reducing built-up areas should be implemented, and abandoned factories and residential lands should be reclaimed for cultivated land. The development of cities in the vertical direction should be explored, and the intensive use of land resources should be adopted as an effective way to balance the challenges of accommodating both carbon storage and rapid urbanization. (3) Rural areas are the main areas producing agricultural products, so the quantity and quality of cultivated land should be guaranteed. In addition, we recommend that grasslands be planted appropriately in lakeside and riparian areas, as this can also enhance carbon storage in the region.

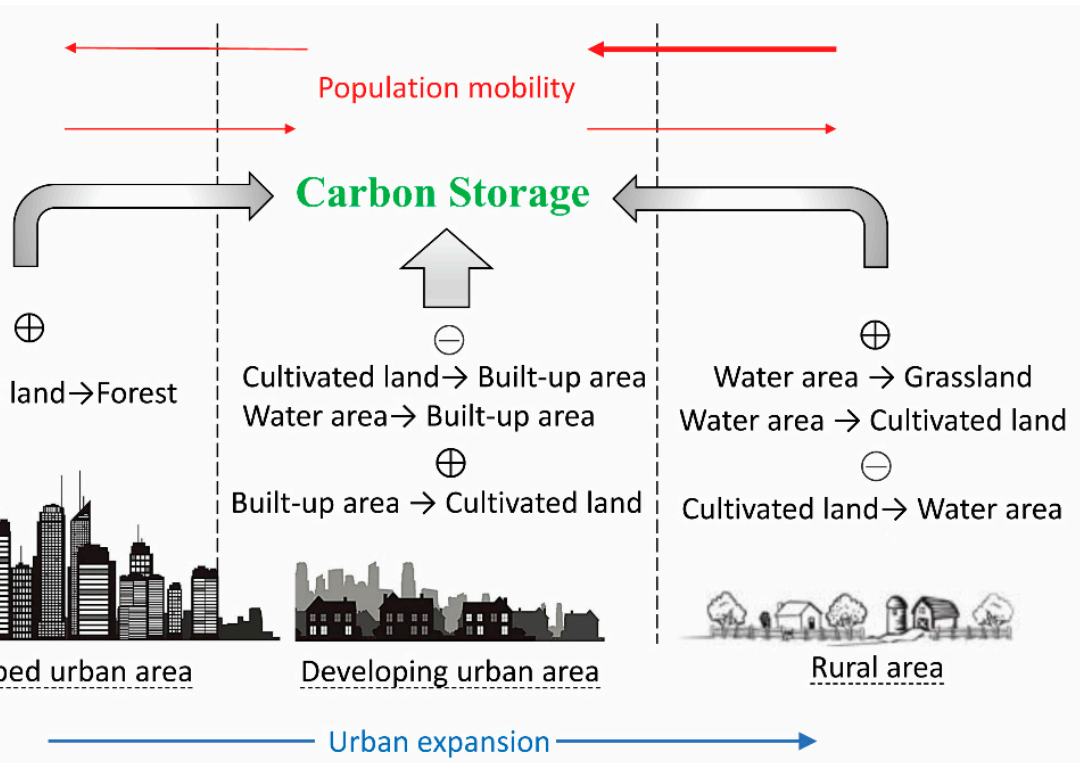

Figure 8. Conceptual diagram of the impacts of urbanization-induced land-use change on carbon storage ("+" and "-" represent the positive and negative impacts of land-use change on carbon storage. The red and blue arrows represent population mobility and urban expansion, respectively).

\subsection{Uncertainties and Limitations}

Although the results of this study reflect the temporal and spatial regularity of carbon storage changes in the context of urbanization, there are also uncertainties. First, the land use data in this study were manually interpreted, which produces some errors and affects the accuracy of the results [65]. Second, the selection of carbon density values affects the accuracy of the results. Under the influence of human activities and environmental changes, the carbon density values will change 
dynamically. However, the InVEST model assumes that carbon density values are constant, which creates uncertainties in the assessment of carbon storage [14]. Finally, the InVEST model simplifies complex ecological processes and enhances the operability of the assessment. However, the model cannot reflect the spatial heterogeneity of carbon storage within each type of land use, which also leads to uncertainties in the assessment results. To improve the accuracy of carbon storage assessments, future research should verify the carbon density values by field surveys and pay attention to the impact of spatial differences within land-use types on carbon densities.

\section{Conclusions}

This study investigated the spatiotemporal dynamics of carbon storage and analyzed the impacts of urbanization-induced land-use changes on carbon storage in the Su-Xi-Chang region. The results revealed that carbon storage exhibits differential responses to urbanization across different urbanization areas and over time. Spatially, the largest loss of carbon storage occurred in developing urban areas, while temporally, the largest loss of carbon storage appeared in the rapidly urbanizing stage. This study further analyzed the drivers of carbon storage changes. Overall, the reduction in cultivated land was the biggest contributor to carbon stock losses. The expansion of built-up areas in developing urban areas and the development of aquaculture in rural areas also resulted in reductions in carbon storage. In addition, the conversion of cultivated lands to forests in developed urban areas, the conversion of built-up areas to cultivated lands in developing urban areas, and the conversion of water areas to cultivated lands and grasslands in rural areas could lead to increases in carbon storage. Based on these results, we recommend that local governments plant trees (e.g., establish urban forest parks) in developed urban areas, implement vertical development and intensive land use in developing urban areas, and increase the area of cultivated lands and grasslands in rural areas. This study can enhance understanding of how to achieve sustainable urbanization. In addition, the methodology and results of our study can be used for reference by researchers of other urban agglomerations around the world.

Author Contributions: Conceptualization, Q.F. and J.C.; methodology, Q.F.; software, H.Z.; formal analysis, Q.F.; writing —original draft preparation, Q.F. and L.X.; writing—review and editing, Q.F.; visualization, Q.F.; supervision, J.C.; project administration, Q.F.; funding acquisition, Q.F.

Funding: This research was funded by the Jiangsu Social Science Foundation (19GLC016), the Major Projects of Philosophical and Social Sciences Research in Colleges and Universities in Jiangsu Province (2019SJZDA043), and the Key Laboratory of Watershed Geographic Sciences, Nanjing Institute of Geography and Limnology, Chinese Academy of Sciences (WSGS2017007).

Acknowledgments: The Suzhou Association of Science and Technology is acknowledged for supporting this study. We would like to thank the anonymous reviewers for their valuable comments and suggestions.

Conflicts of Interest: The authors declare no conflict of interest.

\section{References}

1. Schimel, D.S.; House, J.I.; Hibbard, K.A.; Bousquet, P.; Ciais, P.; Peylin, P.; Braswell, B.H.; Apps, M.J.; Baker, D.; Bondeau, A.; et al. Recent patterns and mechanisms of carbon exchange by terrestrial ecosystems. Nature 2001, 414, 169-172. [CrossRef] [PubMed]

2. Piao, S.; Fang, J.; Ciais, P.; Peylin, P.; Huang, Y.; Sitch, S.; Wang, T. The carbon balance of terrestrial ecosystems in China. Nature 2009, 458, 1009-1013. [CrossRef] [PubMed]

3. Newbold, T.; Hudson, L.N.; Hill, S.L.L.; Contu, S.; Lysenko, I.; Senior, R.A.; Börger, L.; Bennett, D.J.; Choimes, A.; Collen, B.; et al. Global effects of land use on local terrestrial biodiversity. Nature 2015, 520, 45-50. [CrossRef] [PubMed]

4. Leh, M.D.K.; Matlock, M.D.; Cummings, E.C.; Nalley, L.L. Quantifying and mapping multiple ecosystem services change in West Africa. Agric. Ecosyst. Environ. 2013, 165, 6-18. [CrossRef]

5. Pagiola, S. Payments for environmental services in Costa Rica. Ecol. Econ. 2008, 65, 712-724. [CrossRef]

6. Canadell, J.G.; Raupach, M.R. Managing forests for climate change mitigation. Science 2008, 320, $1456-1457$. [CrossRef] 
7. Kashiwagi, H. Atmospheric carbon dioxide and climate change since the Late Jurassic (150 Ma) derived from a global carbon cycle model. Palaeogeogr. Palaeoclimatol. Palaeoecol. 2016, 454, 82-90. [CrossRef]

8. Nelson, E.; Sander, H.; Hawthorne, P.; Conte, M.; Ennaanay, D.; Wolny, S.; Manson, S.; Polasky, S. Projecting global land-use change and its effect on ecosystem service provision and biodiversity with simple models. PLoS ONE 2010, 5, e14327. [CrossRef]

9. Swetnam, R.D.; Fisher, B.; Mbilinyi, B.P.; Munishi, P.K.T.; Willcock, S.; Ricketts, T.; Mwakalila, S.; Balmford, A.; Burgess, N.D.; Marshall, A.R.; et al. Mapping socio-economic scenarios of land cover change: A GIS method to enable ecosystem service modelling. J. Environ. Manag. 2011, 92, 563-574. [CrossRef]

10. Schröter, D.; Cramer, W.; Leemans, R.; Prentice, I.C.; Araújo, M.B.; Arnell, N.W.; Bondeau, A.; Bugmann, H.; Carter, T.R.; Gracia, C.A.; et al. Ecology: Ecosystem service supply and vulnerability to global change in Europe. Science 2005, 310, 1333-1337. [CrossRef]

11. Zhang, M.; Huang, X.; Chuai, X.; Yang, H.; Lai, L.; Tan, J. Impact of land use type conversion on carbon storage in terrestrial ecosystems of China: A spatial-temporal perspective. Sci. Rep. 2015, 5, 10233. [CrossRef] [PubMed]

12. Schulp, C.J.E.; Nabuurs, G.J.; Verburg, P.H. Future carbon sequestration in Europe-Effects of land use change. Agric. Ecosyst. Environ. 2008, 127, 251-264. [CrossRef]

13. Antrop, M. Landscape change and the urbanization process in Europe. Landsc. Urban Plan. 2004, 67, 9-26. [CrossRef]

14. Liu, X.; Wang, S.; Wu, P.; Feng, K.; Hubacek, K.; Li, X.; Sun, L. Impacts of Urban Expansion on Terrestrial Carbon Storage in China. Environ. Sci. Technol. 2019, 53, 6834-6844. [CrossRef] [PubMed]

15. Seto, K.C.; Güneralp, B.; Hutyra, L.R. Global forecasts of urban expansion to 2030 and direct impacts on biodiversity and carbon pools. Proc. Natl. Acad. Sci. USA 2012, 109, 16083-16088. [CrossRef] [PubMed]

16. Chuai, X.; Huang, X.; Lu, Q.; Zhang, M.; Zhao, R.; Lu, J. Spatiotemporal Changes of Built-Up Land Expansion and Carbon Emissions Caused by the Chinese Construction Industry. Environ. Sci. Technol. 2015, 49, 13021-13030. [CrossRef]

17. Zhang, Y.; Wu, Q.; Fath, B.D. Review of spatial analysis of urban carbon metabolism. Ecol. Model. 2018, 371, 18-24. [CrossRef]

18. Mendoza-Ponce, A.; Corona-Núñez, R.; Kraxner, F.; Leduc, S.; Patrizio, P. Identifying effects of land use cover changes and climate change on terrestrial ecosystems and carbon stocks in Mexico. Glob. Environ. Chang. 2018, 53, 12-23. [CrossRef]

19. Ren, Z.; Zheng, H.; He, X.; Zhang, D.; Shen, G.; Zhai, C. Changes in spatio-temporal patterns of urban forest and its above-ground carbon storage: Implication for urban $\mathrm{CO}_{2}$ emissions mitigation under China's rapid urban expansion and greening. Environ. Int. 2019, 129, 438-450. [CrossRef]

20. Liu, R.; Wang, M.; Chen, W. The influence of urbanization on organic carbon sequestration and cycling in soils of Beijing. Landsc. Urban. Plan. 2018, 169, 241-249. [CrossRef]

21. Raciti, S.M.; Hutyra, L.R.; Newell, J.D. Mapping carbon storage in urban trees with multi-source remote sensing data: Relationships between biomass, land use, and demographics in Boston neighborhoods. Sci. Total Environ. 2014, 500, 72-83. [CrossRef] [PubMed]

22. Myeong, S.; Nowak, D.J.; Duggin, M.J. A temporal analysis of urban forest carbon storage using remote sensing. Remote Sens. Environ. 2006, 101, 277-282. [CrossRef]

23. Jiang, W.; Deng, Y.; Tang, Z.; Lei, X.; Chen, Z. Modelling the potential impacts of urban ecosystem changes on carbon storage under different scenarios by linking the CLUE-S and the InVEST models. Ecol. Model. 2017, 345, 30-40. [CrossRef]

24. Zhang, C.; Tian, H.; Pan, S.; Liu, M.; Lockaby, G.; Schilling, E.B.; Stanturf, J. Effects of forest regrowth and urbanization on ecosystem carbon storage in a rural-urban gradient in the southeastern United States. Ecosystems 2008, 11, 1211-1222. [CrossRef]

25. Xu, Q.; Dong, Y.-X.; Yang, R. Influence of land urbanization on carbon sequestration of urban vegetation: A temporal cooperativity analysis in Guangzhou as an example. Sci. Total Environ. 2018, 635, 26-34. [CrossRef]

26. Tian, Y.; Huang, W.; Wu, X.; Jim, C.Y.; Wang, X.; Liu, Y. Dominant control of climate variations over land-use change on net primary productivity under different urbanization intensities in Beijing, China. Acta Ecol. Sin. 2019, 39, 416-424. [CrossRef] 
27. Daily, G.C.; Polasky, S.; Goldstein, J.; Kareiva, P.M.; Mooney, H.A.; Pejchar, L.; Ricketts, T.H.; Salzman, J.; Shallenberger, R. Ecosystem services in decision making: Time to deliver. Front. Ecol. Environ. 2009, 7, 21-28. [CrossRef]

28. Ochoa, V.; Urbina-Cardona, N. Tools for spatially modeling ecosystem services: Publication trends, conceptual reflections and future challenges. Ecosyst. Serv. 2017, 26, 155-169. [CrossRef]

29. Sharp, E.R.; Chaplin-kramer, R.; Wood, S.; Guerry, A.; Tallis, H.; Ricketts, T.; Authors, C.; Nelson, E.; Ennaanay, D.; Wolny, S.; et al. VEST + VERSION + User's Guide; The Natural Capital Project; Stanford University: Stanford, CA, USA; University of Minnesota: Minneapolis, MN, USA; The Nature Conservancy: Arlington, VA, USA; World Wildlife Fund: Gland, Switzerland, 2015.

30. Delphin, S.; Escobedo, F.J.; Abd-Elrahman, A.; Cropper, W.P. Urbanization as a land use change driver of forest ecosystem services. Land Use Policy 2016, 54, 188-199. [CrossRef]

31. Tao, Y.; Li, F.; Liu, X.; Zhao, D.; Sun, X.; Xu, L. Variation in ecosystem services across an urbanization gradient: A study of terrestrial carbon stocks from Changzhou, China. Ecol. Model. 2015, 318, 210-216. [CrossRef]

32. Sallustio, L.; Quatrini, V.; Geneletti, D.; Corona, P.; Marchetti, M. Assessing land take by urban development and its impact on carbon storage: Findings from two case studies in Italy. Environ. Impact Assess. Rev. 2015, 54, 80-90. [CrossRef]

33. Hou, Y.; Mller, F.; Li, B.; Kroll, F. Urban-rural gradients of ecosystem services and the linkages with socioeconomics. Landsc. Online 2015, 39, 1-31. [CrossRef]

34. Larondelle, N.; Haase, D. Urban ecosystem services assessment along a rural—Urban gradient: A crossanalysis of European cities. Ecol. Indic. 2013, 29, 179-190. [CrossRef]

35. Radford, K.G.; James, P. Changes in the value of ecosystem services along a rural-Urban gradient: A case study of Greater Manchester, UK. Landsc. Urban Plan. 2013, 109, 117-127. [CrossRef]

36. Wu, Y.; Tao, Y.; Yang, G.; Ou, W.; Pueppke, S.; Sun, X.; Chen, G.; Tao, Q. Impact of land use change on multiple ecosystem services in the rapidly urbanizing Kunshan City of China: Past trajectories and future projections. Land Use Policy 2019, 85, 419-427. [CrossRef]

37. Wang, J.; Zhou, W.; Pickett, S.T.; Yu, W.; Li, W. A multiscale analysis of urbanization effects on ecosystem services supply in an urban megaregion. Sci. Total Environ. 2019, 662, 824-833. [CrossRef]

38. Lyu, R.; Zhang, J.; Xu, M.; Li, J. Impacts of urbanization on ecosystem services and their temporal relations: A case study in Northern Ningxia, China. Land Use Policy 2018, 77, 163-173. [CrossRef]

39. Xie, W.; Huang, Q.; He, C.; Zhao, X. Projecting the impacts of urban expansion on simultaneous losses of ecosystem services: A case study in Beijing, China. Ecol. Indic. 2018, 84, 183-193. [CrossRef]

40. He, C.; Zhang, D.; Huang, Q.; Zhao, Y. Assessing the potential impacts of urban expansion on regional carbon storage by linking the LUSD-urban and InVEST models. Environ. Model. Softw. 2016, 75, 44-58. [CrossRef]

41. Li, C.; Zhao, J.; Thinh, N.X.; Xi, Y. Assessment of the effects of urban expansion on terrestrial carbon storage: A case study in Xuzhou City, China. Sustainability 2018, 10, 647. [CrossRef]

42. Feng, W.; Liu, Y.; Qu, L. Effect of land-centered urbanization on rural development: A regional analysis in China. Land Use Policy 2019, 87, 104072. [CrossRef]

43. Zhou, D.; Tian, Y.; Jiang, G. Spatio-temporal investigation of the interactive relationship between urbanization and ecosystem services: Case study of the Jingjinji urban agglomeration, China. Ecol. Indic. 2018, 95, 152-164. [CrossRef]

44. Cai, W.; Gibbs, D.; Zhang, L.; Ferrier, G.; Cai, Y. Identifying hotspots and management of critical ecosystem services in rapidly urbanizing Yangtze River Delta Region, China. J. Environ. Manag. 2017, 191, 258-267. [CrossRef] [PubMed]

45. Liu, W.; Zhan, J.; Zhao, F.; Yan, H.; Zhang, F.; Wei, X. Impacts of urbanization-induced land-use changes on ecosystem services: A case study of the Pearl River Delta Metropolitan Region, China. Ecol. Indic. 2019, 98, 228-238. [CrossRef]

46. Chen, C.; Park, T.; Wang, X.; Piao, S.; Xu, B.; Chaturvedi, R.K.; Fuchs, R.; Brovkin, V.; Ciais, P.; Fensholt, R.; et al. China and India lead in greening of the world through land-use management. Nat. Sustain. 2019, 2, 122-129. [CrossRef] [PubMed]

47. Ouyang, Z.; Zheng, H.; Xiao, Y.; Polasky, S.; Liu, J.; Xu, W.; Wang, Q.; Zhang, L.; Xiao, Y.; Rao, E.; et al. Improvements in ecosystem services from investments in natural capital. Science 2016, 352, 1455-1459. [CrossRef] [PubMed] 
48. United Nations Paris Agreement on Climate Change; United Nations Framework Convention on Climate Change: Le Bourget, France, 2015.

49. Fang, J.; Yu, G.; Liu, L.; Hu, S.; Stuart Chapin, F. Climate change, human impacts, and carbon sequestration in China. Proc. Natl. Acad. Sci. USA 2018, 115, 4015-4020. [CrossRef]

50. Long, H.; Liu, Y.; Wu, X.; Dong, G. Spatio-temporal dynamic patterns of farmland and rural settlements in Su-Xi-Chang region: Implications for building a new countryside in coastal China. Land Use Policy 2009, 26, 322-333. [CrossRef]

51. Yirsaw, E.; Wu, W.; Shi, X.; Temesgen, H.; Bekele, B. Land Use/Land Cover Change Modeling and the Prediction of Subsequent Changes in Ecosystem Service Values in a Coastal Area of China, the Su-Xi-Chang Region. Sustainability 2017, 9, 1204. [CrossRef]

52. Wei, Y.D. Beyond the Sunan model: Trajectory and underlying factors of development in Kunshan, China. Environ. Plan. A 2002, 34, 1725-1747.

53. Xie, Y.; Batty, M.; Zhao, K. Simulating emergent urban form using agent-based modeling: Desakota in the Suzhou-Wuxian Region in China. Ann. Assoc. Am. Geogr. 2007, 97, 477-495. [CrossRef]

54. Li, X.; Li, D.; Xu, H.; Wu, C. Intercalibration between DMSP/OLS and VIIRS night-time light images to evaluate city light dynamics of Syria's major human settlement during Syrian Civil War. Int. J. Remote Sens. 2017, 38, 5934-5951. [CrossRef]

55. Li, B.; Chen, D.; Wu, S.; Zhou, S.; Wang, T.; Chen, H. Spatio-temporal assessment of urbanization impacts on ecosystem services: Case study of Nanjing City, China. Ecol. Indic. 2016, 71, 416-427. [CrossRef]

56. Xiang, H.; Jia, M.; Wang, Z.; Li, L.; Mao, D.; Zhang, D.; Cui, G.; Zhu, W. Impacts of Land Cover Changes on Ecosystem Carbon Stocks Over the Transboundary Tumen River Basin in Northeast Asia. Chin. Geogr. Sci. 2018, 28, 973-985. [CrossRef]

57. Guo, X.; Chuai, X.; Zhang, M.; Liang, H.; Li, J.; Zuo, T. Spatio-temporal analysis of land-Use change and the impact on terrestrial ecosystems carbon storage in Yangtze river city group. Resour. Environ. Yangtze Basin 2019, 28, 261-280.

58. Tang, X.; Zhao, X.; Bai, Y.; Tang, Z.; Wang, W.; Zhao, Y.; Wan, H.; Xie, Z.; Shi, X.; Wu, B.; et al. Carbon pools in China's terrestrial ecosystems: New estimates based on an intensive field survey. Proc. Natl. Acad. Sci. USA 2018, 115, 4021-4026. [CrossRef]

59. Bocco, G.; Mendoza, M.; Duhau, E.; Lo, E. Predicting land-cover and land-use change in the urban fringe A case in Morelia city, Mexico. Landsc. Urban Plan. 2001, 55, 271-285.

60. Bai, X.; Chen, J.; Shi, P. Landscape urbanization and economic growth in China: Positive feedbacks and sustainability dilemmas. Environ. Sci. Technol. 2012, 46, 132-139. [CrossRef]

61. Hutyra, L.R.; Yoon, B.; Hepinstall-Cymerman, J.; Alberti, M. Carbon consequences of land cover change and expansion of urban lands: A case study in the Seattle metropolitan region. Landsc. Urban. Plan. 2011, 103, 83-93. [CrossRef]

62. Fei, X. Small town, big issue. In Proceedings of the Seminar on Small Towns in Jiangsu Province, Nanjing, China, 21 September 1983.

63. Pan, Y.; Luo, T.; Birdsey, R.; Hom, J.; Melillo, J. New estimates of carbon storage and sequestration in China'S forests: Effects of age-class and method on inventory-based carbon estimation. Clim. Chang. 2004, 67, 211-236. [CrossRef]

64. Yu, Y.; Guo, Z.; Wu, H.; Kahmann, J.A.; Oldfield, F. Spatial changes in soil organic carbon density and storage of cultivated soils in China from 1980 to 2000. Glob. Biogeochem. Cycles 2009, 23, 1-11. [CrossRef]

65. Hou, Y.; Burkhard, B.; Müller, F. Uncertainties in landscape analysis and ecosystem service assessment. J. Environ. Manag. 2013, 127, S117-S131. [CrossRef] [PubMed]

(C) 2019 by the authors. Licensee MDPI, Basel, Switzerland. This article is an open access article distributed under the terms and conditions of the Creative Commons Attribution (CC BY) license (http://creativecommons.org/licenses/by/4.0/). 